\title{
Nationalism and National Self-Assertion in the People's Republic of China: State Patriotism versus Popular Nationalism?
}

\author{
Phil Deans
}

\begin{abstract}
Nationalism and national self-assertion have been core values of the Chinese Communist Party throughout its history and also represent a key narrative of Chinese history in the 20th century, although the social bases from which the nationalism derives and the manner in which this nationalism is expressed have changed over time. From the 1990s onwards, the party-state's preferred discourse on nationalism has been couched in terms of patriotism, while a popular nationalism has emerged, which at times goes beyond and challenges that of the party-state. The implications of this are addressed in the present paper with regard to the PRC's relations with Taiwan and Japan and with regard to the debate on ideology and Asian Values. It is argued that rising popular nationalism increasingly challenges state autonomy in the first two areas, but tends to be supportive of the state with regard to the third.
\end{abstract}

\section{Introduction}

National self-assertion has been a core value of Chinese political elites since before the formation of the People's Republic in 1949. However, only since the 1990s has the Chinese state been able to exert sustained influence over regional and global politics. The 1990s witnessed an increase in the economic, political and military capabilities of the Chinese state, together with the emergence of a discourse of popular nationalism in China which at times goes beyond the aims and objectives of the Chinese Communist Party (CCP). Nationalism is understood here to be a series of domestic political and social forces and sentiments, whereas national self-assertion is the translation of those forcesinto state policy and state action. While the CCP has always sought to mobilize nationalism to secure its legitimacy, the new 'popular' nationalism is 
Phil Deans

increasingly a constraint on, and a potential threat to, its leadership. In the context of self-assertion, this leads to a reduction of state autonomy in a range of areas, including policy toward Taiwan, the United States and Japan. One area where self-assertion is less problematic for the $\mathrm{CCP}$ is the Chinese challenge to the liberal ideology of key international financial institutions and the universal aspirations of the human rights regime. What has emerged in recent years is a tension between the state nationalist project and the aspirations of popular nationalism, and the key issue for the future is whether the 'Fourth Generation' of leaders under President Hu Jintao will act as a moderating influence on growing popular demands for China to assert itself, or find themselves forced to be its representatives - the 'fourth'representation.

This paper locates the tradition of Chinese self-assertion through a consideration of the nationalist discourses that have emerged in China in the 20th century. It is argued that a consideration of contending nationalisms offers one possible explanatory narrative for political change and action in China. It is suggested that nationalism in China has emerged as a response to imperialism and modernity and can be useful categorized into two discrete forms. On the one side is a conservative nationalism, rooted in the cities and amongst the Chinese bourgeoisie, which sought inspiration from western liberal and democratic thinking. On the other is a radical nationalism, rooted in the countryside and amongst the peasantry and working classes and seeking inspiration from the western tradition. These two nationalist responses to modernity coalesced in the Chinese Civil War, which saw the communists victorious on the Chinese mainland (Deans 2005).Subsequently, Chinese nationalism in the PRC remains dominated by state objectives because of the pervasive control of society that resulted from the authoritarian Leninist structure of the PRC. However, the economic and political reforms in China since 1978 have seen the CCP transform itself into a conservative nationalist party. So while radical nationalism has withered, the CCP now confronts a popular nationalism from Chinese society which increasingly acts as a constraint on its ability to pursue rational and coherent strategies.

This paper addresses three areas where the changing dynamics within Chinese nationalism are having an impact on Chinese selfassertion: the relationship with Taiwan, relations with Japan, and the PRC's relationship with international regimes and organizations. With regard to Taiwan, it is argued that the 'wait and see' policy pursued by the Chinese leadership since the late 1990s may be challenged by growing popular demands for the Taiwan issue to be resolved, and 
the Chinese leadership's ability to compromise with the Taiwanese authorities is constrained by popular sentiment. A similar argument is developed with regard to Sino-Japanese relations, where strong antiJapanese sentiment in China already places limits on the CCP's ability to improve relations with Japan for the sake of the economic reform programme. Popular demands for greater national self-assertion against Japan threaten the ability of the CCP to pursue a rational and mature relationship. Finally, self-assertion is less problematic with regard to the PRC's participation in international regimes, although this may lead to a degree of conflict with other countries, particular the United States of America and member countries of the European Union. The Chinese government'semphasis on the principle of sovereignty and its criticism of the western approach to human rights and the economic ideologies of some international financial institutions garner domestic support from important sectors within China, in addition to support from developing countries in Asia and Africa.

The ongoing dynamics of Chinese nationalism do not lend themselves to straightforward categorization. Data are contested and interpretations have become highly politicized. This is due to a number of factors, such as the pressures of the Cold War on western scholarship or because of ongoing debates regarding China's changing political and economic significance since the end of the Cold War, and the implications of this for Europe, North America and China's Asian neighbours. The analysis here tries to recentre China within discourses on Chinese history and nationalism, as suggested by Paul Cohen (Cohen 1984). This discourse will be straightforward (although not necessarily uncontroversial) to most readers familiar with the contemporary scholarship on Chinese history (Pepper 2004), although such discussion rarely features in the literature on China during the Cold War (Saull 2001; Westad 2000). This paper suggests one possible heuristic narrative which identifies a spectrum of nationalist responses. Moreover it suggests that political agency focuses these into two dominant strands: a conservative and a radical nationalism, which comprise the two key forms of Chinese response to modernity in the 20th century. In turn this narrative helps elucidate issues bound up with contemporary Chinese nationalism. 


\section{Nationalism and Legitimacy in the Reform Period: State Patriotism versus Popular Nationalism}

Since the foundation of the PRC, the CCP has derived a key source of its legitimacy from its nationalist credentials and its pursuit of a nationalist project. Of course, the CCP's legitimacy derived from more than just this source - its programmes of social and economic reform were also vital-but these programmes were inseparable from the nationalist agenda (Pepper 2004).From the early 1950s until the 1980s the CCP routinely mobilized nationalism as a vehicle to maintain its power and achieve its objectives. The PRC in this period (with the possible exception of the chaotic first two years of the Cultural Revolution, 1966-68) was a strongly authoritarian Leninist regime in which the party-state aspired to exercise almost total control over society. However, by the late 1970s and following the death of Mao, the CCP faced increasing problems with its legitimacy. The mistakes within the Great Leap Forward and the Cultural Revolution, the death of the charismatic revolutionary leader, and the visible reconfigurations of the PRC's international relations all combined to undermine the authority of the CCP. Deng Xiaoping's response was to begin a series of political and economic reforms to reinvigorate the economic credentials of the CCP. While economic legitimacy was the key strategy for Deng, appeals to patriotism remained important throughout the 1980s, and Pye, Zheng and others have argued that nationalism increasingly replaces Marxism-Leninism as the underlying ideology of CCP rule (Pye 1996; Zheng 1999). Nonetheless, as the Leninist authoritarianism of the Mao period declined, the CCP faced increasing challenges from Chinese society, especially during periods of economic difficulty.

The CCP leadership continued to appeal to Chinese nationalism (minzuzhuyi) to legitimize its role, using state media and the education system to promote a particular vision of China and its future. However, disagreements within the leadership over emphasis and tensions over nationalist aspirations within the Chinese periphery (most notably in Taiwan and Tibet) saw a shift towards a more inclusive patriotism (aiguozhuyi).Patriotism in this context is inspired by a 'love of country' that is accessible to all citizens of the state, whereas nationalism is typically a more narrow ideology centred on a specific ethnic group. In this way, 'patriotism' should be seen as the officially sanctioned discourse of nationalism in China (Zheng 1999: 88). Immediately after the turmoil of the student-led reform movement in 1989, the CCP under the direction of Jiang Zemin and Li Ruihuan initiated a series of patriotic 
campaigns which focused on China's past humiliations and on the role of the CCP in defending China (Zhongyaowenxian zhaibian 1990). As Xu demonstrates, anniversaries of 'public humiliations' such as the Opium Wars were commemorated with a very high profile by the senior leadership (Xu 2001), and this culminated in 1994 with the publication of the 'Outline for the Implementation of Patriotic Education' (Renmin Ribao, 6 September 1994).

Significantly, nationalism and patriotism became the rallying cry of those who challenged the CCP on a range of issues. In the 1980s many Chinese intellectuals paid great attention to western countries as potential models for China, and there was widespread criticism of many aspects of China's past as being a hindrance to China's development. However, the 1990s saw the emergence of a growing rejection of the west and western models and focus on 'Chinese'solutions to China's problems (Xu 2001). The student-led reform movement of 1989 is perhaps the turning point in the emergence of a new, popular nationalist discourse in the PRC to exist outside the control of the Communist Party. The excellent analysis of China's new nationalism by Peter Hays Gries shows how growing nationalist sentiment in Chinese society during the 1990s increasingly became a problem for the Chinese leadership (Gries 2004). The mid-1990s saw a growing expression of popular nationalism through the publication of books such as Song et al.'s Zhongguo keyi shuo 'bu' [The China that Can Say 'No'](Songet al.1996) and the widespread use of the internet as a vehicle for discussion by Chinese nationalists (Deans 2004b). While the CCP has continued to mount patriotic campaigns and engage in the promotion of nationalism as a mechanism for promoting legitimacy, a popular nationalist discourse has increasingly offered a challenge to the CCP, as was seen in popular reaction to the dispute with Japan over control of the Diaoyutai/Senkaku Islands, the bombing of the Chinese embassy in Belgrade, and the death of a Chinese pilot following a collision with an American spy plane (Gries 2004).

What is interesting about the PRC is that the end of the Cold War, an event that dominates the politics and international relations of Europe and North America, is relatively unimportant with regard to China's relations with other Asian countries. It is significant mainly in the context of the PRC-USA relationship, but the fundamental shift in the PRC's relations with other Asian countries takes place in the 1970s. There has been a tendency in the literature to overstate the significance of the end of the Cold War for the PRC. In the 1990s it has been the internal dvnamics of the reform process and the unresolved tensions within Chinese 
Phil Deans

nationalism, rather than change in the international system, that has had most significance for Chinese self-assertion.

Complementarity between the economic goals of the reform programme and national self-assertion is not guaranteed. The greatest tensions exist when more narrowly defined nationalist objectives conflict with the wider economic priorities of the reform programme. This is visible in a number of policy areas, including the PRC's approach to cross-Strait relations and bilateral relations between the PRC and the United States and Japan. Conflicts exist in the Chinese leadership over the relative emphasis that should be placed on national self-assertionand economic growth, and these tensions, combined with growing popular nationalist aspirations, may significantly hinder the autonomy of the Chinese state to pursue rational and coherent strategies in this regard.

The Chinese state remains very powerful, but it is no longer able to exercise the all-pervasive power of Chinese society that it enjoyed before the start of the reform programme in 1978. The reform programme has seen a gradual and ongoing reduction in both state autonomy (the ability of the central government to make planning decisions without excessive or undue influence over these decisions) and state capacity (the ability to physically implement a decision once it is taken, i.e. to enforce the law, make local authorities follow central directives and to extract, regulate, legitimate and coerce) (Deans 2004a). As was shown in 1989, when faced with serious levels of unrest, the CCP is able and willing to use lethal force to ensure its continuing rule, but the costs of this are well understood by the leadership. The costs must be counted not just in human terms, but in potential damage to the Party's credibility, economic costs in terms of the impact of falling investment and possible sanctions, and the damage done to the PRC's international reputation and prestige and pursuit of a peaceful and stable international environment.

Maintaining high levels of surveillance and control over society, especially in the context of new forms of media such as the internet, is expensive and possibly unsustainable (Deans 2004b). The senior Chinese leadership fears that public pressure over an ostensible 'patriotic' concern-such as the desire for national reunification with Taiwan or holding Japan to account for its past abuses of China-may result in direct attacks on say, American or Japanese interests in the PRC. Even more troubling, the criticism could be directed at the CCP's handling of these events, and snowball into mass anti-government demonstrations that mobilize nationalism as a mechanism to attack the CCP. Controlling 
and policing this kind of unrest is possible in the short term, but the medium- to long-term costs could be highly damaging, especially if, as in 1989, the protestors seek legitimacy though appeals to nationalism. It is in this area that state patriotism could clash with popular nationalism, and where societal demands for greater self-assertion by the Chinese state could lead to conflict, both within the PRC and between the PRC and other members of international society.

\section{Self-Assertion and the Unresolved Civil War: Cross-Strait Relations}

There is little doubt that tensions exist between, on the one hand, the CCP's use of nationalism and patriotism and the objectives of the economic reform programme and, on the other, the calls for a peaceful and stable international environment to foster China's development. These tensions are manifest in a number of policy areas, particularly in the cross-Strait relationship with Taiwan, where the unresolved Chinese civil war continues to challenge the CCP's legitimacy, albeit in new ways. The recovery of Taiwan is of fundamental importance to the nationalist project of the CCP. Indeed, reunification with Taiwan represents the key remaining component of the ambition of national reunification and bringing down the curtain on the 'century of shame and humiliation' that the Chinese people suffered at the hands of western and Japanese imperialism (Deans 2005). PRC policy toward Taiwan has undergone significant shifts since 1949, and the key strategy at present appears to be one of attempting to lock the Taiwanese economy into the Chinese developmental trajectory while maintaining a hard line on Taiwan's international status. Taiwan has become a major investor into the PRC, and a vibrant and dynamic economic relationship has developed over the last 15 years. However, the emergence of a separatist Taiwanese nationalism challenges the overarching CCP objectives, and the Chinese leadership's response to the changes on Taiwan could threaten the key aspects of the reform process by generating a regional military conflict.

Cross-Strait relations from the early 1990s to the present demonstrate an intrinsic contradiction. By most quantitative measures, Taiwan and the Chinese mainland have never been closer. Trade, investment and exchange of peoples across the Strait have boomed since official restrictions on indirect trade and travel were lifted. There is more exchange across the Taiwan Strait today than at any time in the past-whethercompared to when Taiwan was on the periphery of the Qing empire or when the 
island was a colony of Japan. Added to this, the economic differences between Taiwan and the wealthier parts of the PRC such as Shanghai and Guangdong are far less apparent than they were when cross-Strait exchanges resumed in 1988. However, by most qualitative measures the two sides have never been further apart. Although the economic system in the PRC increasingly resembles the strong-state capitalist system of Taiwan, the political systems register a strong divide, with an increasingly democratic Taiwan offering a contrast to the soft authoritarianism of the PRC. Most importantly in the context of Chinese nationalism, the political differences between the Chinese leadership in Beijing and the current Democratic Progressive Party regime of Chen Shui-bian have never been greater. In particular, a growing number of people on Taiwan no longer identify themselves with China (or, at least, the PRC's vision of China) and there is a growing sympathy for the idea of establishing an independent Taiwanese state. The conservative nationalism of the Chiang Kai-shek and Chiang Ching-kuo eras has given way in the 1990s to an assertive Taiwanese nationalism which has seen identity politics hijack the emerging democratic institutions and electoral discourse (Shih 2003a). Political competition in Taiwan has been increasingly defined around the dynamics of Taiwanese identity and the future status of the island vis-ì-vis its relationship with the People's Republic.

For the CCP the national mission of reunification is central to its legitimacy, and Taiwan is the most important element in this programme. While the Taiwan issue was peripheral to CCP concerns before it came to power, since 1949 it has repeatedly made public claims that Taiwan and the Chinese mainland will be reunified. The official position is clear and direct:

The Chinese government and people absolutely have the determination and ability to safeguard China's sovereignity and territorial integrity, and will never tolerate, condone or remain indifferent to the reslization of any scheme to divide China. (The Taiwan Question and Reunification of China 1993)

Any survey of Chinese government statements and announcements on the Taiwan question makesit clear that the issue is of the highestimportance to the Chinese leadershipand that all methods, including the use of military force, will be used to prevent Taiwanese independenceor to ensureeventual reunification. In 1995 and 1996 the Chinese leadershipfound it necessary to engagein a series of military exercises to demonstrate to both the Taiwan and the United States the seriousness with which the CCP regarded the question of reunification (Zhao1999).However, despite its occasional martial public rhetoric, since the 1996 crisis the Chinese leadership has followed a passive 
policy of 'wait and see' toward Taiwan (Zhao 2003) and has avoided provoking pro-independence sentiment on Taiwan. The 'wait and see' policy and attempts at accommodation by the CCP have continued in the face of concerted efforts by former President Lee Teng-hui and then by President Chen Shui-bian to delay, stall or derail attempts at restarting the dialogue across the Strait that began in the early 1990s (Deans 2005). However the extension of the discourse on patriotism to Hong Kong, and the use of the term 'unpatriotic'being applied to critics of Beijing, have generated concerns in both Hong Kong and Taiwan over the use of this agenda to define the politically acceptable and unacceptable (Kyodo, 13 February 2004).

While the senior leadership of the CCP has pursued a cautious strategy toward Taiwan, it has found itself confronted with growing dissatisfaction at the speed and pace of the quest for reunification. For popular nationalists in the PRC the Taiwan issue brings together all the key elements of the 'century of shame-China's weakness in the 19th century, Japanese imperialism, and US interventionism in the Cold War. Added to this are the psychological issues of rejection that are generated by the refusal of many Taiwanese to 'return to the motherland'. The CCP still retains considerable mechanisms for asserting and maintaining control over popular dissent in the PRC, but the levers of control are not as pervasive as they were under Mao. The CCP's uncertainty that it would be able to control popular anger over the Taiwan question means that its ability to pursue a strategy of 'wait and see' and to offer compromises to the Taiwanese over the time and terms of reunification are constrained. Clearly, Taiwanese investment in the Chinese economic development agenda is important, and the goal of a peaceful international environment within which to promote economic growth remains central to the CCP'scurrent objectives. However, the dangers to the CCP's authority of moves toward independence by Taiwan are such that the Chinese leadership may find that it can only retain authority if it responds militarily to unilateral attempts by the Taiwanese to change the status quo in the Strait. Moreover, opinion in the PRC toward the Taiwan question appears to be hardening (Straits Times, 15 June 2004). The Anti-Succession Law that was passed by the National People's Congress in March 2005 should be viewed in this context-although it must be remembered that this law did not change PRC policy toward Taiwan, it merely provided a legal framework which recognized a long-standing policy position. This leaves the Chinese leadership in the precarious position of hoping that the US can constrain an increasingly erratic Taiwanese leadership from provoking conflict (Shih 2003b). 
Phil Deans

\section{The Limits of Pragmatism:Self-Assertion, Popular Nationalism and Sino-JapaneseRelations}

It is a common assumption in liberal readings of international relations that growing interaction and contact, and in particular increased commercial and business exchange, increase mutual understanding and deepen interdependence between countries. This is turn is expected to lead to improved relations (Yahuda n.d.). However, this has not been an obvious result of growing Sino-Japanese interaction, and it appears that the opposite may be the case with anti-Japanese sentiment being increasingly apparent in the PRC and anti-Chinese sentiment also on the rise in Japan. For example, it is reported that the growing number of Chinese students studying in Japan are leaving the country with their prejudices reinforced (Taipei Times, 29 March 2004). Self-assertion and popular nationalism have generated clear problems with regard to the PRC's relations with Japan. The relationship with Japan has been the PRC's most difficult partnership as the relationship exists in the shadow of a tragic history of Japaneseaggression in China before 1945, and this history has been contested and exploited for political purposes by the government and nationalist groups on both sides. Fifty years of Japanese aggression and imperialism have become central to the ongoing discourse of Chinese identity and Chinese nationalism, and popular antiJapanese sentiment in the PRC appears to be growing (Shih 2000).

Japan and the People's Republic of China established diplomatic relations in 1972, and the first 15 years of relations were marked by growing economicinteraction and a degree of common political cause, with some commentators regarding the period 1972-89 as the 'golden age' of SinoJapanese relations (Vogel et al. 2002). Nonetheless, this period was not without problems as the historical legacy of poor relations continued to factor in the relationship. Disputes over the portrayals of history in Japanese school textbooks (Rose1998), the visit of Japaneseleaders to the Yasukuni Shrine (Yang2002), the nature of any official Japanese apology for its aggression against China (Gries 2004), the territorial dispute over control of the Diaoyu/Senkaku Islands (Deans 2000), and Japan's informal relations with Taiwan (Deans 2002) ensured a background of disaffection throughout this period. One important issue was the way in which intra-elite conflict in the Chinese leadership often used the issue of Japan as a cloak for opposition to the reform programme-the dismissal of $\mathrm{Hu}$ Yaobang in 1987 was surrounded by an atmosphere that $\mathrm{Hu}$ was too sympathetic to the Japanese. 
The Japanese government took a pragmatic approach to the events of 1989 in China and the suppression of the student-led reform movement in Tiananmen Square, and was the first G7 country to lift sanctions against Beijing. In the 1990s Japan, along with the Untied States, was the most important foreign player in China's rapid economic growth and was the most important single provider of overseas development assistance. However the political climate, at the popular if not the government level, continued to deteriorate. Writing some five years ago, Rose suggested that because the nationalism apparent in both China and Japan was 'inward-oriented', it was unlikely to have a seriously negative impact on the bilateral relationship (Rose 2000). However, subsequent events have shown that the popular antagonism in the relationship has constrained the ability of the government to allow the relationship to develop in a more mature manner, and one influential Japanese interpretation places responsibility firmly with JiangZemin and the Patriotic Education Campaigns of the 1990s (Torii 2004).

While the Chinese state's attempts at promoting nationalism and patriotism to secure its legitimacy have been significant, popular national self-assertion over relations with Japan has far exceeded what the leadership regards as acceptable and has become a serious problem in maintaining a stable relationship with Japan. Nationalism has always been the key motor of the territorial dispute over the Diaoyu/Senkaku Islands (Deans 2000). While remaining resolute in their stated position of claming sovereignty over the islands, both the Chinese and Japanese have been at pains to downplay the dispute in the context of the wider political and economic interests at stake in the bilateral relationship. Nevertheless, the islands are the subject of frequent clashes between nationalists on both sides and the ongoing dispute over the Diaoyu/ Senkaku Islands has continued to threaten the relationship. The visit of Japan'sForeign Minister Kawaguchi Yoriko to Beijing in April 2004 was overshadowed by a group of Chinese nationalists landing on the islands. The Japanese government responded by arresting the Chinese and then sending them back to China (Kyodo, 4 April 2004) which in turn angered Japanese nationalists who believed the Chinese should have been subjected to legal process.

In 2003 angry Chinese responses to a series of incidents, ranging from the discovery of Japanese chemical weapons stockpiles left over from the war against China to the activities of Japanese sex tourists in the PRC, demonstrated the depth of popular hostility toward Japan. Chinese activists used the internet to organize petitions demanding apologies 
from Japan and compensation for those who had suffered as a result of Japan'saction before 1945, and it was reported that over one million signatures were obtained (BBCOnline, 18 September 2003). The serious nature of the popular swell of anti-Japanese opinion was demonstrated clearly during the Asian Cup football tournament where the Japanese team was subjected to abuse by Chinese supporters, with Japaneseflags being burnt and players threatened (BBC Online, 7 August 2004).

The problem posed by rising anti-Japanese sentiment in China is recognized by the Chinese government, and the visit to Beijing in April 2004 by the Japanese Foreign Minister Kawaguchi Yoriko is reported to have expressed her concern about the possible negative impact of 'patriotic'material on Chinese web sites. The Chinese are understood to have responded that the Japanese government must do more to prevent incidents that damage the bilateral relationship (Kyodo, 4 April 2004). Where attempts have been made by Chinese intellectuals to improve the climate of the debate over relations with Japan, there has often been a furious backlash from popular nationalists in the PRC. Perhaps the most important case was that of Ma Licheng, a high-profile writer and critic associated with liberal and progressive politicians. Ma wrote an article in the influential journal Zhanlue yu guanli [Strategy and Management] calling for 'new thinking' on China's relations with Japan, in particular suggesting that the issue of history be put to one side (Ma 2002). A heated debate followed in scholarly journals over Ma's analysis, but the popular reaction was one of fury, especially on the internet.

As with the case of Taiwan, anti-Japanese popular sentiment in the PRC is not able to determine policy, but it can restrict the arena available for public debate and discussion about Japan. In turn this may limit the ability of the Chinese leadership to improve relations with its key regional trade and investment partner. As in the case of Taiwan, popular demands for growing self-assertion against Japan threaten to reduce state autonomy. While the Chinese leadership appears to want to pursue a pragmatic policy toward Japan, the mobilisation of the historical legacy in the context of popular Chinese nationalism constantly limits the ability of the Chinese leadership to develop and maintain a coherent relationship. 


\section{Self-Assertion versus Universalism: Ideology and Asian Values}

There are areas of self-assertion by the Chinese state which may meet with a degree of popular acceptance but that can lead the PRC into disagreements and possible (non-military) conflict with the west; one such area is in the ideological (or ideational) realm. Self-assertion on the international stage can be seen as the PRC exercising soft power in international society. However, the CCP's normative preferences are likely to be significantly different from those of the dominant western states. Self-assertion by the Chinese leadership therefore may bring the PRC into conflict with some of the norms and values expressed by western states, while generating support for the PRC from other non-western developing countries. Chinese self-assertion in the ideological realm has manifested itself in criticism of the aims and logic of the 'universalism' that underpins many western claims about human rights. It also brings the CCP into conflict with the liberal economic philosophy that underpins much of the development discourse of institutions such as the World Bank and the International Monetary Fund.

International organizations and international regimeshave become key institutions in international society since the end of the Second World War. International Organisations (IOs) are institutions usually with formal bureaucracies and established rules and procedures. Typically membership comprises states, and the highest profile IO is the United Nations (UN). Kim has argued that, 'most of the time, on most global issues, Chinese international organisation behaviour is symbolic rather than substantive' (Kim1994: 407). Kim is correct to highlight the importance of symbolism in Chinese behaviour but perhaps oversimplifies the extent to which symbolism is substance for the Chinese leadership, particular in the context of national self-assertion. A very important subset of international organizations is the International Financial Institutions (IFIs) such as the World Bank (WB), the International Monetary Fund (IMF) and the World Trade Organization (WTO).It is important to note that none of the major international organizations is value neutral - the UN operates entirely through the system of sovereign statehood, and the IFIs are dominated by their major donors, in particular the United States. As such, the IFIs tend to promote economic ideologies which concur with the key objectives of the United States, typically favouring economic liberalism, privatization and deregulation, a position which in the 1990s became known as the Washington Consensus (Helleiner 2003). 
Phil Deans

The Chinese leadership appears to have embraced multilateralism in recent years, especially with regard to economic fora. The highestprofile move has been joining the WTO, but since 2000 the PRC has also increased its participation in a number of regional fora, especially with Southeast Asian countries (Cheng 2004). However, it is still not clear the extent to which the PRC has begun to internalize the norms of these institutions. It does appear that the PRC leadership views these institutions in instrumental terms, and is most concerned with how China can benefit from participation in a 'realist' way, rather than viewing the institution in terms of the wider goals that institutionalism may provide (Wan2001). The Chinese government has been effective at avoiding many of the more stringent demands on funding that the IMF has placed on other developing countries, and has taken a principled position in international fora of criticizing the liberal assumptions of IMF and World Bank practice. Indeed, China's pursuit of an economic strategy in direct contravention of the Washington Consensus has led one economist to describe the emergence of a 'BeijingConsensus' among developing countries (Foreign Policy, 2004). While demonstrating a clear preference for Anglo-American economic norms, Perkins argues that the PRC remains a very long way from complying with the standards prescribed by the IMF and WTO but suggests that these IFI recognise China's achievements to date (Perkins 2003). Greater reintegration into the world economic system is likely to further undermine the autonomy of the Chinese state to pursue independent economic strategies (Deans 2004a). Indeed, self-assertion by opponents of China's growing integration in the world economy is already significant, as is most clearly demonstrated in the high-profile book Qianqiuhua yingiingxia de Zhongguo zhi lu [China's Road in the Shadow of Globalization] (Fang et al. 1999).

Another area where China may find that self-assertion leads to conflict with other countries is in its approach to international regimes. An international regime is typically defined as, 'sets of implicit or explicit principles, norms, rules, and decision making procedures around which actors' expectations converge in a given area of international relations' (Krasner 1983: 2). One of the most important regimes in current times is that which addresses human rights, with a key document being the United Nations Declaration on Human Rights (Dunne and Wheeler 1999). The Chinese leadership has been critical of a number of the assumptions that underlie the human rights agenda as developed by the west, and has consistently followed a line of pointing to the primacy of second-generation socio-economic rights over first-generation political 
rights (Progress in China's Human Rights Cause, 2003). As Xu has shown, the 1990s - especially before the Asian financial crisis of 1997-saw significant criticism of western approaches to human rights and attempts at applying 'universal' standards to the region (Xu 2001). Inside the PRC an increasingly lively academic debate exists around the usefulness and applicability of the idea of rights (Weatherley 2001). To some extent, China's criticism of the international human rights regime is self-serving and seeks simply to deflect criticism. However, it is also underpinned by a significant and sophisticated philosophical position that challenges many of that assumptions that inform liberal thinking on rights (Bell 2000; Brown 1999). Chinese self-assertion with regard to rights has manifested in the PRC's international diplomacy, most notably in the preparatory meetings which preceded the 1993 Vienna World Conference on Human Rights. The Chinese delegation played a lead role in the pre-meeting in Thailand which resulted in the 'Bangkok Declaration'. The Bangkok Declaration outlined a significant number of issues that question the western approach to the human rights regime, in particular by its added attention to socio-economic rights and by reference to the importance of sovereignty in international society.

China's position on the human rights question is important because it has an international and external dimension. As Wachman has shown, the attempts to 'shame' China into complying with western human rights standards have not only been of limited effectiveness, but may prove counterproductive and lead to increasing disaffection with western human rights proponents (Wachman 2001). Therefore the Chinese government's criticism of the international human rights regime may be a mechanism for exploiting popular anti-foreign sentiment. Furthermore, by taking a lead role in criticizing aspects of the international human rights regime, the Chinese leadership can be seen as engaging in the construction and exercise of 'soft power'. Nye explains that'[s]oft power is the ability to get what you want by attracting and persuading others to adopt your goals' (Nye 2003). The Chinese leadership has been able to use its position on rights to gain the respect of other Asian and African countries which are troubled by the approach the west takes on human rights questions.

\section{Implications and Conclusions}

All indications are that the fourth-generation leadership in the PRC intends to focus on creating an environment that will promote economic growth and development. However, the legitimacy of the CCP is lever- 
aged not solely on generating improved living standards but also on promoting the Chinese nationalist project. Increasingly the Chinese leadership is under pressure from elements within Chinese society, not only to deliver the economic goods, but also to satisfy growing nationalist aspirations. At times these objectives may be complementary, however on occasion there will be significant contradictions between the two, and popular pressure may reduce state autonomy. In terms understood and developed by Mao Zedong, the Party must ensure that when contradictions arise between economic reform and nationalist aspirations, that these remain non-antagonistic contradictions. In this context self-assertion may be a demonstration of weakness, rather than strength. Where self-assertion is more likely to be dynamic is in ideological realms, such as criticism of the western universal pretensions or American unilateralism. This is less likely to generate problems within the domestic realm, and may also win support for the PRC from other developing and less developed countries. However, arguments about the liberal economic assumptions that underpin the World Bank and International Monetary Fund may damage China's relations with these institutions, and China's willingness to challenge the claims of western human rights advocates is likely to further complicate dialogue with western states.

The PRC leadership is keen to reassure its regional neighbours and global partners that China's rise is peaceful, as can be seen in a series of public statements by fourth-generation leaders since late 2003 (Jiefang Ribao, 26 April 2004). Furthermore intellectuals and commentators linked to President Hu have been promoting the 'peaceful rise' (heping jueqi) theory in Chinese media, although not without some opposition from the third-generation leadership (Suettinger 2004). With reference to prospects for greater regional cooperation, the PRC leadership is likely to pursue this only where it will not antagonize popular nationalist sentiment. Recent years have seen the Chinese leadership engage increasingly with regional multilateral institutions, particularly economic institutions, and the Chinese leadership has skilfully managed to ease fears in much of Southeast Asia over China's growing economic strength. However, the issue of sovereignty is so deeply connected to the nationalist agenda that any political changes will be very cautious. As such, it is unlikely that the Chinese leadership would promote any form of greater co-operation that envisaged a dilution of sovereignty, such as that pursued by western European countries since the 1950s.

National self-assertion in China and the rise of popular nationalism have important implications for non-regional powers such as the United 
States and the European Union. Chinese nationalism is likely to respond negatively to outside involvement or intervention, and therefore outside powers are best advised to wait for invitation rather than threaten intervention. It is likely that any attempts by outside powers to intervene in what the Chinese people regard as domestic matters will generate a significant domestic pressure on the Chinese government. This was seen most starkly following the death of a Chinese pilot following a collision with a US spy place in 2002, but also manifests itself in the growing antagonism that western condemnation of human rights in China has generated. For the PRC's partners and China's neighbours, a weak Chinese leadership and a weak China poses a much greater challenge than a strong and coherent China. The greatest challenge faced by the leadership of the CCP does not come from pressures for democracy and openness, but from reactionary and chauvinistic popular nationalism. The 'Three Represents' campaign calls on the Chinese leadership to represent progressive social forces; the challenge for $\mathrm{Hu}$ Jintao is to avoid becoming the representative of the forces of reaction.

Phil Deans is Director at the Contemporary China Institute, Department of Politics and International Studies, University of London, School of Oriental and African Studies.

\section{REFERENCES}

BBC Online, 18 September 2003. 'Anti-Japan Protests Worry China.' http://news.bbc.co.uk/l/hi/world/asia-pacific/3118850.stm, accessed on $15 \mathrm{Au}$ gust 2004.

BBC Online, 7 August 2004. 'Chinese Riot after Japan Victory.'

http://news.bbc.co.uk/1/hi/world/asia-pacific/3541380.stm, accessed on $15 \mathrm{Au}$ gust 2004.

Bell, Daniel A. 2000. East Meets West: Human Rights and Democracyin East Asia. Princeton: Princeton University Press.

Brown, Chris 1999. 'Universal Human Rights: a Critique'. In T. Dunne and N. J. Wheeler (eds), Human Rights in Global Politics. Cambridge: Cambridge University Press: 102-27.

Cheng, Y. S. 2004. 'The ASEAN-China Free Trade Area-Genesis and Implications.' Australian Joumal of Intemational Affairs 8(2) June: 257-77.

Cohen, Paul A. 1984. Discovering History in China: American Historical Writing on the Recent Chinese Past. New York: Columbia University Press.

Deans, Phil 2000. 'Contending Nationalisms in Northeast Asia and the Diaoyutai/ Senkaku Dispute.' Security Dialogue 31(1) March:119-31.

- 2002. 'The Taiwan Question: Reconciling the Irreconcilable.'In Marie Soderberg (ed.), Chinese-JapaneseRelations in the Twenty-first Century. London: Routledge: 88-102.

- 2004a. 'The People's Republic of China: the Post-socialist Developmental State.' In 
Phil Deans

Linda Low (ed.), Developmental States: Relevancy, Redundancy or Reconfiguration? Singapore and New York: Nova Science: $135-48$.

- 2004b 'The Internet in the People's Republic of China: Censorship and Participation.' In Jason P. Abbott (ed.), The Political Economy of the Internet in Asia and the Pacific: Digital Divides, Economic Competitiveness and Security Challenges. Praeger: Greenwood Publishing: 123-38.

- 2005. 'Cross Straits Relations since 1949: From Radicalism to Conservatism and Back Again.' In G. Schucher and M. Schueller (eds), Perspectives on Cross-Strait Relations: Views from Europe. Hamburg: Institute of Asian Affairs:35-54.

Dunne, Tim and Nicholas J. Wheeler 1999. 'Introduction: Human Rights and the Fifty Years' Crisis.' In T. Dunne and J. Wheeler (eds), Human Rights in Global Politics. Cambridge: Cambridge University Press: 1-28.

Fang Ning, Wang Xiaodong and Song Qiang 1999. Qianqiuhua yingjingxia de Zhongguo zhi $l u$ [China's Road in the Shadow of Globalization] Beijing: Zhongguo Shehui Kexue chubanshi.

Foreign Policy, September/October 2004. 'Too Much Consensus.' http://www.foreignpolicy.com/story/files/story2678.php, accessed on 15 September 2004.

Gries, Peter Hays 2004. China's New Nationalism: Pride, Politics and Diplomacy. Berkeley and Los Angeles: University of California Press.

Helleiner, Eric 2003. 'EconomicLiberalism and its Critics: the Past as Prologue?' Review of International Political Economy 10(4) November: 685-96.

Jiefang Ribao, 26 April 2004. 'Zhonguo heping jueqide daolu xuanze he zhanlue guannian.'[TheStrategy and pursuit of China's 'PeacefulRise']. http://www.people. com.cn/GB/guandian/1035/2468305.html, accessed 15 August 2004.

Kim, Samuel S. 1994. 'China's International Organisation Behaviour.' In Thomas W. Robinson and David Shambaugh (eds), Chinese Foreign Policy: Theory and Practice. Oxford: Clarendon Press: 401-34.

Krasner, Stephen D. 1983. 'Structural Causes and Regime Consequences: Regimes as Intervening Variables.' In Stephen D. Krasner (ed.), International Regimes. Ithaca: Cornell University Press: 1-22.

Kyodo, 2004a. 'H.K. Politicians Lock into Debate on Patriotism.' 13 February.

Kyodo, 2004b. 'Japan:China Say Bilateral Ties Important despite Differences.' 4 April.

Ma, Licheng 2002. 'Dui Ri guanxi xin siwei: Zhong-Ri minjian zhiyou' [New Thinking on Relations with Japan:Sino-Japanese Public Disaffection]. Zhanlüe yu guanli [Strategy and Management] 6: 41-7.

Nye, Joseph S. Jr 2003. 'Propaganda Isn't the Way: Soft Power.' International Herald Tribune, 10 January.

Pepper, Suzanne 2004. 'The Political Odyssey of an Intellectual Construct: Peasant Nationalism and the Study of China's Revolutionary History - a Review Essay.' Journal of Asian Studies 63(1) February: 105-25.

Perkins, D. H. 2003. 'China: Converging or What?' Cambridge Reviezv of International Affairs 16(1) April: 71-8.

Progress in China's Human Rights Cause 2003. White Paper. Accessed 19 August 2004: http://www.china.org.cn/e-white/20040330/index.htm.

Pye, Lucien 1996. 'How China's Nationalism was Shanghaied.' In Jonathan Unger (ed.), Chinese Nationalism. Armonk: M. E. Sharpe: 86-112.

Renmin Ribao, 1994. 'Aiguozhuyi jiaoyu shishi gangyao' [Outline for Implementing Patriotic Education] 6 September: 1.

Rose, Caroline1998. Interpreting History in Sino-Japanese Relations: a Case Study in Political Decision Making. London: Routledge. 
- 2000. "'Patriotismis Not Taboo" - Nationalism in China and Japan and Implications for Sino-Japanese Relations.' Japan Forum 12(2): 169-81.

Saull, Richard 2001. Rethinking Tlzeory and History in the Cold War: Tlze State, Military Power and Social Revolution. London: Frank Cass.

Shih, Chih-yu 2000. 'Defining Japan: the Nationalist Assumption in China's Foreign Policy.'In Chih-yu Shih, Reform, Identity and Chinese Foreign Policy. Taipei: Vanguard Institute for Policy Studies: 227-48.

- 2003a. 'The Global Constitution of "'Taiwan Democracy": Opening up the Image of a Successful State after 9/11.' East Asia: an International Quarterly 20(3) Fall: 16-38.

- 2003b. 'Talking American, Acting Taiwanese: Behind Taipei's Complete Compliance of the Bush Doctrine.' Asian Perspective 27(4): 79-110.

Suettinger, Robert L. 2004. 'The Rise and Descent of "Peaceful Rise."' China Leadership Monitor 12 Fall. http://www.chinaleadershipmonitor.org/20044/rs.pdf, accessed on 5 September 2004.

Song, Qiang, Zhang Zangzang and Qiao Bian 1996. Zhongguo keyi shuo bu [The China that Can Say 'No'].Hong Kong: Mingbao.

Straits Times, 2004. 'Chinese Mood against Taipei Independence Growing.' 15 June.

Taipei Times, 2004. 'JapanStrains to Welcome Foreign Students' 29 March: 5.

The Taizuan Question and Reunification of China 1993. White Paper. Beijing:Taiwan Affairs Office and Information Office State Council, August.

Torii, Tami 2004. 'Han-Nichi' de ikinobiru Clzugoku [China: Sustaining Itself on AntiJapanese Sentiment]. Tokyo: Sokushisha.

Vogel, Ezra F., Yuan Ming and Tanaka Akihiko (eds) 2002. Tlze Golden Age of tlze US-China-Japan Triangle, 1972-1989. Cambridge MA and London: Harvard University Press.

Wachman, Alan 2001. 'Does the Diplomacy of Shame Promote Human Rights in China?' Third World Quarterly 22(2): 275-81.

Wan, Ming 2001. Human Rights in Clzinese Foreign Relations: Defining and Defending National Interests. Philadelphia: University of Pennsylvania Press.

Weatherley, Robert 2001. 'The Evolution of Chinese Thinking on Human Rights in the Post-Mao Era.' Journalof Communist Studies and Transition Politics 17(2) June:19-42.

Westad, Odd-Arne (ed.)2000. Reviezuing the Cold War: Approaches, Interpretations, Theory. London: Frank Cass.

Xu, Guangqiu 2001. 'Anti-Western Nationalism in China, 1989-99'. World Affairs, Spring.

Yahuda, Michael n.d. 'The Limits of Economic Interdependence.' Accessed 29 April 2004: http://www.isanet.org/archive/yahuda.doc.

Yang, Daqing 2002. 'Mirror for the Future or the History Card? Understanding the "History Problem".' In MarieSoderberg (ed.),Chinese-JapaneseRelationsin tlze TwentyFirst Century. London: Routledge: 10-31.

Zhao, Suisheng (ed.) 1999. Across the Taiwan Strait: Mainland China, Taiwan and tlze 1995-96 Missile Crisis. London: Routledge.

- 2003. 'Beijing'sWait and See Policy toward Taiwan: An Uncertain Future.' East Asia: an International Quarterly 20(3) Fall.

Zheng, Yongnian 1999. Discovering Clzinese Nationalism in China: Modernization, Identity and International Relations. Cambridge: Cambridge University Press.

Zhongyao wenxian zlzaibian 1990 . 'Zai xin de lishi tiaojianxia jichenghe fayang aiguozhuyi chuantong - shiyi jie san zhong quanhui yilai youguan zhongyao wenxian zhaibian' [Continue to Promote the Traditions of Patriotism in the New Historical Era - Extracts from Important Documents since the Third Plenum of the $11^{\text {th }}$ Party Congress]. Beijing: Hongqi chubanshe. 